\title{
Measurements of hydrogen peroxide and formaldehyde exchange between the atmosphere and surface snow at Summit, Greenland
}

\author{
Hans-Werner Jacobi ${ }^{\mathrm{a}, *}$, Markus M. Frey ${ }^{\mathrm{a}}$, Manuel A. Hutterlia ${ }^{\mathrm{a}}$, Roger C. Bales ${ }^{\mathrm{a}}$, \\ Otto Schrems ${ }^{\mathrm{b}}$, Nicolas J. Cullen ${ }^{\mathrm{c}}$, Konrad Steffen ${ }^{\mathrm{c}}$, Cathi Koehler ${ }^{\mathrm{d}}$ \\ a Department of Hydrology and Water Resources, University of Arizona, P.O. Box 210011, 1133 E. North Campus Dr., Tucson, \\ AZ 85721-0011, USA \\ ${ }^{\mathrm{b}}$ Alfred Wegener Institute for Polar and Marine Research, Am Handelshafen 12, 27570 Bremerhaven, Germany \\ ${ }^{\mathrm{c}}$ CIRES, CB 216, University of Colorado, Boulder, CO 80309, USA \\ ${ }^{\mathrm{d}}$ Manchester High School, Earth and Space Science, Manchester, CT 06040, USA
}

Received 6 June 2001; received in revised form 7 September 2001; accepted 17 September 2001

\begin{abstract}
Tower-based measurements of hydrogen peroxide $\left(\mathrm{H}_{2} \mathrm{O}_{2}\right)$ and formaldehyde $(\mathrm{HCHO})$ exchange were performed above the snowpack of the Greenland ice sheet. $\mathrm{H}_{2} \mathrm{O}_{2}$ and $\mathrm{HCHO}$ fluxes were measured continuously between 16 June and 7 July 2000, at the Summit Environmental Observatory. The fluxes were determined using coil scrubber-aqueous phase fluorometry systems together with micrometeorological techniques. Both compounds exhibit strong diel cycles in the observed concentrations as well as in the fluxes with emission from the snow during the day and the evening and deposition during the night. The averaged diel variations of the observed fluxes were in the range of $+1.3 \times 10^{13}$ molecules $\mathrm{m}^{-2} \mathrm{~s}^{-1}$ (deposition) and $-1.6 \times 10^{13}$ molecules $\mathrm{m}^{-2} \mathrm{~s}^{-1}$ (emission) for $\mathrm{H}_{2} \mathrm{O}_{2}$ and $+1.1 \times 10^{12}$ and $-4.2 \times 10^{12}$ molecules $\mathrm{m}^{-2} \mathrm{~s}^{-1}$ for $\mathrm{HCHO}$, while the net exchange per day for both compounds were much smaller. During the study period of 22 days on average $\left(0.8_{-4.3}^{+4.6}\right) \times 10^{17}$ molecules $\mathrm{m}^{-2}$ of $\mathrm{H}_{2} \mathrm{O}_{2}$ were deposited and $\left(7.0_{-12.2}^{+12.6}\right) \times$ $10^{16}$ molecules $\mathrm{m}^{-2}$ of $\mathrm{HCHO}$ were emitted from the snow per day. A comparison with the inventory in the gas phase demonstrates that the exchange influences the diel variations in the boundary layer above snow covered areas. Flux measurements during and after the precipitation of new snow shows that $<16 \%$ of the $\mathrm{H}_{2} \mathrm{O}_{2}$ and more than $25 \%$ of the $\mathrm{HCHO}$ originally present in the new snow were available for fast release to the atmospheric boundary layer within hours after precipitation. This release can effectively disturb the normally observed diel variations of the exchange between the surface snow and the atmosphere, thus perturbing also the diel variations of corresponding gas-phase concentrations. (C) 2002 Elsevier Science Ltd. All rights reserved.
\end{abstract}

Keywords: Hydrogen peroxide; Formaldehyde; Greenland; Air-snow exchange; Tropospheric composition; Polar atmospheric chemistry

\footnotetext{
*Corresponding author. Present address: Alfred Wegener Institute for Polar and Marine Research, Am Handelshafen 12, 27570 Bremerhaven, Germany.

E-mail address: hwjacobi@awi-bremerhaven.de (H.-W. Jacobi).
}

\section{Introduction}

Formaldehyde (HCHO) and hydrogen peroxide $\left(\mathrm{H}_{2} \mathrm{O}_{2}\right)$ are key compounds regarding the chemical composition of the Earth's atmosphere. Both are important secondary products formed during the oxidation of organic compounds (e.g. Jenkin and 
Clemitshaw, 2000). At the same time, they influence the oxidation capacity of the troposphere because they are important precursors of radicals like $\mathrm{OH}$ and $\mathrm{HO}_{2}$ (Crawford et al., 1999). Therefore, both compounds have been used to investigate photochemical processes in the troposphere (e.g. Weller et al., 2000; Lee et al., 2000; Chance et al., 2000) and to validate the performance of numerical photochemistry models (e.g. Jaeglé et al., 2000; Solberg et al., 2001).

Recently, $\mathrm{HCHO}$ and $\mathrm{H}_{2} \mathrm{O}_{2}$ in polar regions have attracted a lot of interest due to two different reasons. It has been discussed that $\mathrm{HCHO}$ and $\mathrm{H}_{2} \mathrm{O}_{2}$ can play critical roles in the atmospheric boundary layer (ABL) at high latitudes during the occurrence of ozone $\left(\mathrm{O}_{3}\right)$ depletion events that are commonly observed during polar sunrise in Arctic areas (McConnell et al., 1992). While the effective $\mathrm{O}_{3}$ destruction is caused by reactions with chlorine $(\mathrm{Cl})$ and bromine $(\mathrm{Br})$ atoms (Barrie et al., 1988, 1994; Mickle et al., 1989; Bottenheim et al., 1990; Jobson et al., 1994; Solberg et al., 1996; Ariya et al., 1998; Ramacher et al., 1999), $\mathrm{Cl}$ and $\mathrm{Br}$ atoms also react quickly with $\mathrm{HCHO}$ and are transformed into nonreactive compounds like $\mathrm{HCl}$ and $\mathrm{HBr}$ that are subsequently removed from the gas phase (Barrie et al., 1988; Shepson et al., 1996). In contrast, Michalowski et al. (2000) pointed out that the reaction of $\mathrm{HCHO}$ with $\mathrm{BrO}$ might lead to the formation of $\mathrm{HOBr}$ initiating subsequent heterogeneous reactions increasing halogen atom concentrations. $\mathrm{H}_{2} \mathrm{O}_{2}$ could also contribute to the formation of gas-phase molecular bromine $\left(\mathrm{Br}_{2}\right)$ as a consequence of the reaction of $\mathrm{H}_{2} \mathrm{O}_{2}$ with bromide $\left(\mathrm{Br}^{-}\right)$ in the aqueous phase (McConnell et al., 1992). Besides the involvement of both compounds in important photochemical processes, $\mathrm{H}_{2} \mathrm{O}_{2}$ and $\mathrm{HCHO}$ are conserved in surface snow and ice cores providing valuable information about the oxidation capacity of the past troposphere (Staffelbach et al., 1991; Thompson et al., 1993; Neftel et al., 1995; Fuhrer et al., 1996; Hutterli et al., 1999, 2001). Knowledge of the exchange between the atmosphere and the underlying snowpack is important for the development of transfer functions that link concentrations in the snowpack and in the gas phase.

Gas-phase $\mathrm{H}_{2} \mathrm{O}_{2}$ and $\mathrm{HCHO}$ concentrations have been investigated at several different sites in the Arctic. Combined field and modeling studies have indicated, that current gas-phase chemistry models are unable to account for $\mathrm{H}_{2} \mathrm{O}_{2}$ (Neftel et al., 1995; McConnell et al., 1997a; Hutterli et al., 2001) and HCHO concentrations (McConnell et al., 1992; De Serves, 1994; Sander et al., 1997; Rudolph et al., 1999; Hutterli et al., 1999) commonly observed at high latitudes. Model results also indicate that emissions from the snowpack can sustain measured gas-phase concentrations of $\mathrm{H}_{2} \mathrm{O}_{2}$ and HCHO (Shepson et al., 1996; Michalowski et al., 2000; Hutterli et al., 1999, 2001). Nevertheless, only few attempts have been made to measure fluxes above the snowpack. Vertical HCHO profiles at Alert, Canada, presented by Sumner and Shepson (1999), displayed higher concentrations close to the snow surface compared to ambient concentrations. Moreover, Hutterli et al. (1999) calculated HCHO fluxes from the snowpack at Summit, Greenland, using either measured ambient and interstitial air concentrations or surface snow measurements that are sufficiently high to compete with known $\mathrm{HCHO}$ formation pathways in the gas phase. Hutterli et al. (2001) also reported diel variations of $\mathrm{H}_{2} \mathrm{O}_{2}$ fluxes above the snowpack indicating a temperature-driven recycling between air and snow.

In this paper we report observations of $\mathrm{H}_{2} \mathrm{O}_{2}$ and HCHO gradients above a snowpack combined for the first time with direct measurements of diffusion coefficients using eddy correlation technique. The impact of the derived fluxes on observed diel variations in the ABL is discussed. A precipitation event is analyzed to demonstrate how regular diel variations of concentrations and fluxes are effectively disturbed by emissions from new snow.

\section{Experimental}

Ambient gas-phase concentrations of $\mathrm{H}_{2} \mathrm{O}_{2}$ and $\mathrm{HCHO}$ were continuously measured at the Greenland Environmental Observatory Summit (GEO Summit) on top of the Greenland ice sheet $\left(72.6^{\circ} \mathrm{N}, 38.5^{\circ} \mathrm{W}, 3200 \mathrm{~m}\right.$ elevation) from 5 June to 9 July 2000 . Ambient air was drawn through heated and insulated inlet lines $(0.635 \mathrm{~cm}$ ID PFA tubes) to the analyzers installed in a trench located $400 \mathrm{~m}$ south of the main camp and $\sim 3 \mathrm{~m}$ below the snow surface. From 16 June to 7 July gradient measurements of both compounds above the snowpack were performed. For this purpose the inlet line was mounted on a lift that automatically switched every $8 \mathrm{~min}$ between two heights ( 1 and 152 or 1 and $143 \mathrm{~cm}$ ). Because the concentrations could be affected by contamination from emissions of the main camp the data was filtered using ambient $\mathrm{NO}_{x}$ and $\mathrm{NO}_{y}$ concentrations (Honrath et al., this issue). Concentrations were discarded when either $[\mathrm{NO}] \geqslant 100 \mathrm{pptv}$ or $\left[\mathrm{NO}_{x}\right] \geqslant 200$ pptv or $\left[\mathrm{NO}_{y}\right] \geqslant 1000$ pptv. When $\mathrm{NO}_{x}$ and $\mathrm{NO}_{y}$ concentrations were not available, data were also abandoned if the wind came from northerly directions $\left(330^{\circ} \leqslant \mathrm{WD} \leqslant 30^{\circ}\right)$.

Gas-phase $\mathrm{H}_{2} \mathrm{O}_{2}$ and $\mathrm{HCHO}$ were absorbed from the sample air stream into an aqueous solution using coil scrubbers followed by derivatization and fluorometric detection. Both instruments have previously been described in detail (Hutterli et al., 2001; Riedel et al., 1999). $\mathrm{H}_{2} \mathrm{O}_{2}$ was stripped from an ambient airflow $\left(\sim 1.21 \mathrm{~min}^{-1}(\mathrm{STP})\right)$ by $\mathrm{H}_{2} \mathrm{O}_{2}$ free water running at $\sim 0.2 \mathrm{ml} \mathrm{min}^{-1}$ ) into a coil scrubber. After raising the $\mathrm{pH}$, the aqueous phase $\mathrm{H}_{2} \mathrm{O}_{2}$ concentration was 
analyzed by UV fluorescence spectroscopy after derivatization with 4-ethylphenol in the presence of peroxidase. Calibrations were performed daily by running liquid standards through the scrubber while flushing with $\mathrm{H}_{2} \mathrm{O}_{2}$-free air generated by pumping ambient air through a column filled with manganese dioxide-copper oxide mixture (Hopcalite ${ }^{\mathbb{R}}$, Callery Chemical Company, USA). The same zero air was used to monitor the baseline every hour. The limit of detection (LOD) of the instrument was 70 pptv corresponding to 3 times the standard deviation of the noise level measured with zero air and the accuracy was estimated to be better than $25 \%$. It is well known that the applied method is also sensitive to higher organic peroxides (Lee et al., 2000). Therefore, we used a second channel equipped with a manganese dioxide catalyst to selectively destroy $\mathrm{H}_{2} \mathrm{O}_{2}$ (Lee et al., 2000). The signal of the second channel always remained below the detection limit in agreement with previous data from Summit (Sigg et al., 1992) and gives us confidence that organic peroxides did not interfere substantially with our $\mathrm{H}_{2} \mathrm{O}_{2}$ measurements. Gas-phase $\mathrm{HCHO}$ concentrations were obtained using a commercial analyzer (AL4001, Aero-Laser GmbH, Germany). HCHO was collected by drawing air $\left(\sim 0.6-0.81 \mathrm{~min}^{-1}(\mathrm{STP})\right)$ and pumping acid solution $\left(0.05 \mathrm{M} \mathrm{H}_{2} \mathrm{SO}_{4}\right)$ at a rate of $\sim 0.2 \mathrm{ml} \mathrm{min}^{-1}$ together into a coil scrubber. The analysis in the aqueous phase is based on the Hantzsch reaction of HCHO with pentane2,4-dione and $\mathrm{NH}_{3}$ followed by fluorometric detection. While the reaction chamber and the fluorescence cell were kept at $60^{\circ} \mathrm{C}$, the scrubber was held at a constant temperature of $16^{\circ} \mathrm{C}$ to increase the stripping efficiency to more than $96 \%$ (Riedel et al., 1999). The zero air for the $\mathrm{H}_{2} \mathrm{O}_{2}$ instrument was also used to hourly determine the baseline for the HCHO measurements. A LOD of 30 pptv and an accuracy of $<25 \%$ were achieved.

The primary flux measurement systems utilized to determine the turbulent structure of the near-surface boundary layer were two eddy covariance (EC) systems including two three-dimensional sonic anemometers with fine wire thermocouples and two ultraviolet hygrometers (CSAT3, FW05, KH20; all Campbell Scientific, USA) mounted on profile arms 1 and $2 \mathrm{~m}$ above the snow surface, respectively. These instruments were reoriented so that they pointed into the prevailing wind direction during the measurement period. The measurements were performed at $50 \mathrm{~Hz}$ using a data logger (CR5000, Campbell Scientific, USA) connected directly to a computer housed near the measurement tower. Supporting measurements were wind speed, temperature and relative humidity measured at $0.5,1$, and $2 \mathrm{~m}$ above the snow surface on a separate tower. A three-dimensional coordinate rotation on the time series $u, v$, and $w$ were performed after Kaimal and Finnigan (1994), which aligned the time series with the mean wind vector, forcing $v$ and $w$ means to zero. Turbulence statistics were generated for 10 min periods in post processing to coincide with those calculated from the supporting measurements. The two EC systems were utilized to investigate the accuracy of the turbulence measurements resulting in deviations of $<15 \%$ in all cases (Cullen and Steffen, 2001).

Further micrometeorological data (temperature, wind speed, wind direction, pressure, relative humidity) is available on the web pages of GEO Summit (http:// www.hwr.arizona.edu/geosummit/data.html).

\section{Results}

Fig. 1 shows observed $\mathrm{HCHO}$ and $\mathrm{H}_{2} \mathrm{O}_{2}$ time series. Due to different experiments the inlets were mounted at different heights. The time series presented here are assembled from all measurements at heights between 1 and $2 \mathrm{~m}$ above the snow surface. For the measuring period from 5 June until 8 July 2000, average concentrations were 0.65 and 120 pptv for $\mathrm{H}_{2} \mathrm{O}_{2}$ and $\mathrm{HCHO}$, respectively. An increasing trend for $\mathrm{HCHO}$ was observed with average concentrations of $<100 \mathrm{pptv}$ in the first week and almost 180 pptv in the last week. Most of the days both compounds exhibit diel cycles with low concentrations during the night and higher concentrations during the day as shown in Fig. 2. However, maximum concentrations are reached either in the evening $\left(\mathrm{H}_{2} \mathrm{O}_{2}\right)$ or in the morning ( $\left.\mathrm{HCHO}\right)$.

Fluxes of $\mathrm{HCHO}$ and $\mathrm{H}_{2} \mathrm{O}_{2}$ were determined using an integrated flux-gradient approach based on MoninObukhov similarity theory. Direct measurements of the heat and momentum fluxes using the eddy correlation technique enabled determination of the Obukhov length $L$, a key independent variable in the steady state, horizontally homogenous ABL. Specification of the flux-profile relationships required to calculate fluxes of $\mathrm{HCHO}$ and $\mathrm{H}_{2} \mathrm{O}_{2}$ reduces to knowledge of the stability function $\phi_{\mathrm{m}}$ as a function of $z / L$ (e.g. Businger et al., 1971; Dyer, 1974) with the height above the snow surface $z$. Once functions of $\phi_{\mathrm{m}}$ were established changes to the turbulent exchange coefficient for momentum $\left(K_{\mathrm{m}}\right)$ with stability were determined, enabling fluxes of $\mathrm{HCHO}$ and $\mathrm{H}_{2} \mathrm{O}_{2}$ to be expressed in terms of concentration gradients in the vertical direction $z$ using Eq. (1):

$$
F=K_{\mathrm{m}}(z) \frac{\partial C}{\partial z}=\frac{\kappa u_{*} z}{\phi_{\mathrm{m}}(z / L)} \frac{\partial C}{\partial z}=\text { const. }
$$

with von Karman constant $\kappa(=0.4)$, friction velocity $u_{*}$, and concentration $C$. Since the application of the fluxprofile relationship also includes the premise of constant fluxes with height, Eq. (1) can be solved in the integrated form (2).

$$
F=\frac{\kappa u_{*} \int_{C\left(z_{1}\right)}^{C\left(z_{2}\right)} \partial C}{\int_{z_{1}}^{z_{2}}\left(\phi_{\mathrm{m}}(z / L) / z\right) \partial z}=\frac{\kappa u_{*}\left(C\left(z_{2}\right)-C\left(z_{1}\right)\right)}{\int_{z_{1}}^{z_{2}}\left(\phi_{\mathrm{m}}(z / L) / z\right) \partial z} .
$$




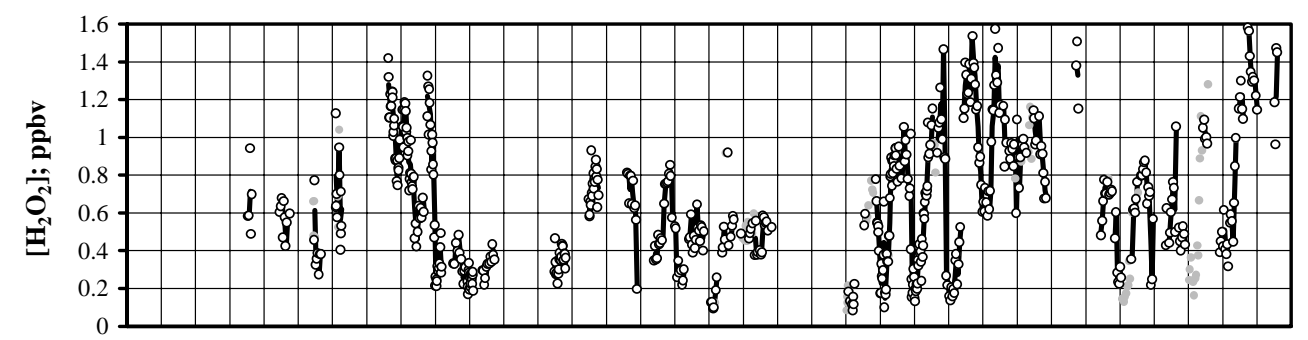

(a)

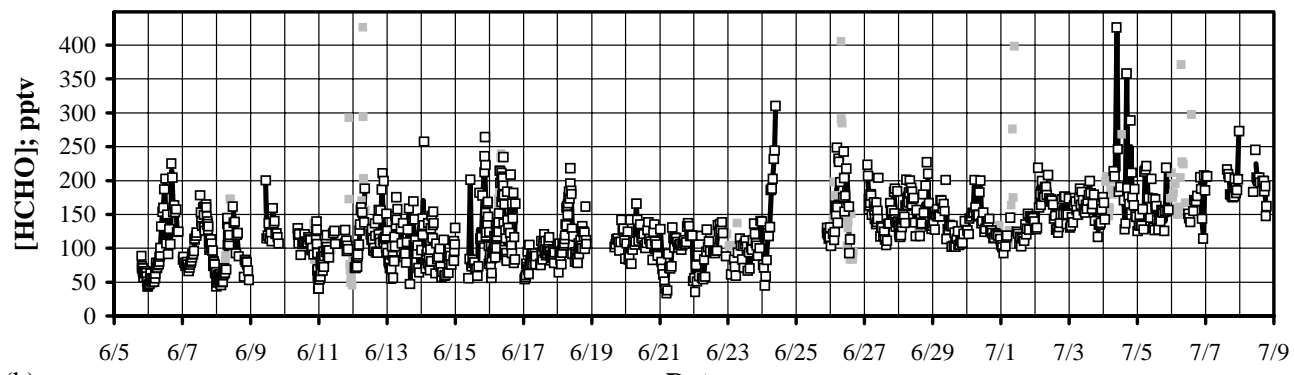

(b)

Date

Fig. 1. Time series of $\mathrm{H}_{2} \mathrm{O}_{2}$ (a) and $\mathrm{HCHO}$ (b) concentrations measured at Summit, Greenland, in June-July 2000. Symbols mark $10 \mathrm{~min}$ averages; lines show $1 \mathrm{~h}$ averages. Grey symbols indicate discarded data (see text) also including HCHO concentrations between 400 and 1400 pptv (not shown).

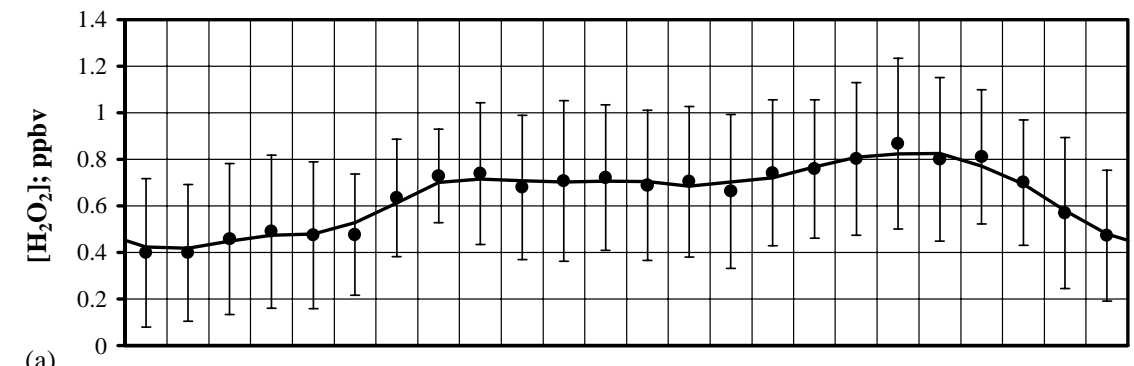

(a)

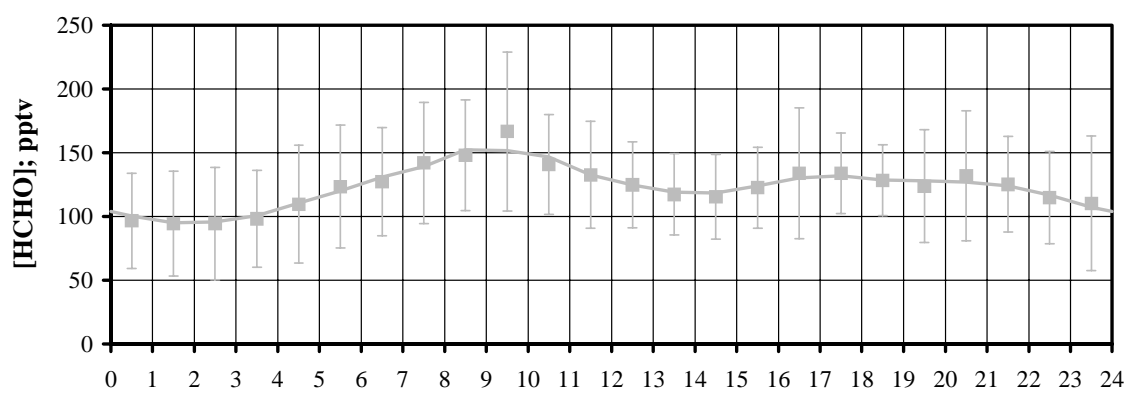

(b)

Hour (Local time)

Fig. 2. Diel variations of $\mathrm{H}_{2} \mathrm{O}_{2}$ (a) and $\mathrm{HCHO}$ (b) concentrations measured at Summit, Greenland, in June-July 2000. Symbols mark $1 \mathrm{~h}$ bins; lines show $3 \mathrm{~h}$ running averages. Error bars indicate calculated standard deviations.

Gradient measurements, friction velocities, and Obukhov lengths are available for a 22-day period (16 June-7 July). For unstable conditions the stability function $\phi(z / L)=(1-16 z / L)^{-0.25}$ was used, while for stable cases the function $\phi(z / L)=1+4.6 z / L$ was applied, which reduces under neutral conditions $(L \gg 1)$ to $\phi(z / L)=1$. Because the concentrations were alternately measured at two heights with an integration time 


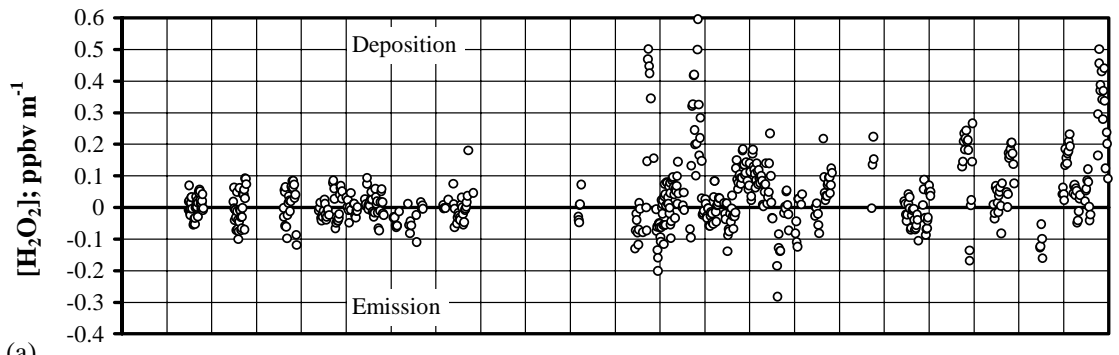

(a)

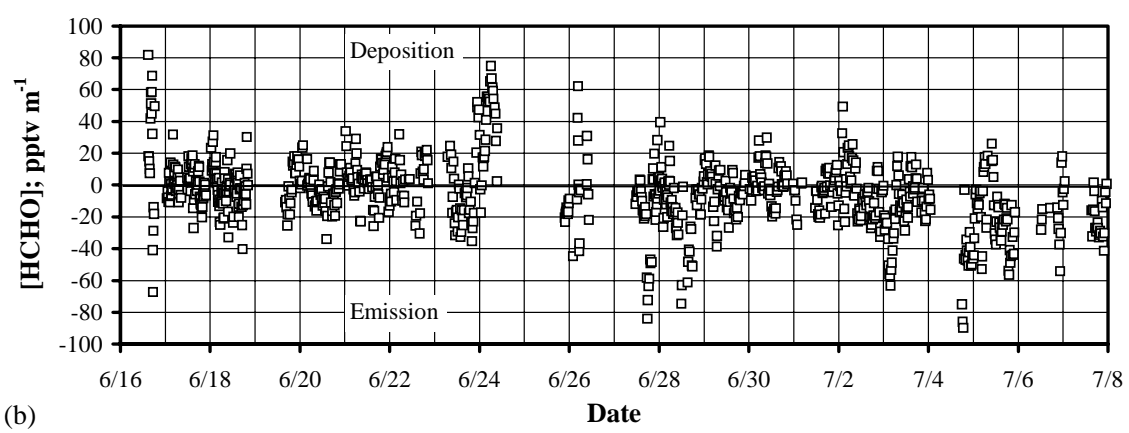

Fig. 3. Time series of $\mathrm{H}_{2} \mathrm{O}_{2}$ (a) and $\mathrm{HCHO}$ (b) concentration gradients measured at Summit, Greenland, in June-July 2000.

of $8 \mathrm{~min}$ at each height, consecutive measurements in one height were used to linearly interpolate the value at one height for the point of time of the measurement at the other height. The concentration gradients shown in Fig. 3 were calculated as (upper level concentration measurement)-(lower level concentration measurement). As a result, a positive gradient represents trace gas deposition and a negative gradient indicates trace gas emission. Each gradient was used to calculate the flux with the appropriate micrometeorological coefficients. The fluxes for the whole period were averaged within $1 \mathrm{~h}$ bins to obtain average diel variations for both compounds (Fig. 4). Average $\mathrm{H}_{2} \mathrm{O}_{2}$ fluxes vary between +1.3 and $-1.6 \times 10^{13}$ molecules $\mathrm{m}^{-2} \mathrm{~s}^{-1}$. On the other hand, average $\mathrm{HCHO}$ fluxes show a smaller amplitude between +1.1 and $-4.2 \times 10^{12}$ molecules $\mathrm{m}^{-2} \mathrm{~s}^{-1}$. Fig. 4 also indicates the range of the middle $50 \%$ of the flux data that were used to calculate errors of the amounts exchanged between air and snow per day (Table 1). These errors and ranges illustrate that the observed fluxes exhibit a large variability, which is mainly caused by an inherent natural variability of the fluxes due to variable meteorological conditions. Compared to the natural variability, uncertainties in the flux calculations and analytical errors are small. Nevertheless, the 50\% range also demonstrates that a majority of the individual diel cycles measured on different days follow distinct patterns, reflected by the averaged diel variations of both compounds, with common features like emissions during the day and deposition during the night. The average turning point from deposition to emission occurs around 10:00 in the morning for $\mathrm{H}_{2} \mathrm{O}_{2}$ and
HCHO. While HCHO emissions continue until midnight, $\mathrm{H}_{2} \mathrm{O}_{2}$ fluxes change their directions already at 17:00 in the evening. Highest average $\mathrm{H}_{2} \mathrm{O}_{2}$ deposition rates were observed between 17:00 and 21:00 in the evening. The average net fluxes during the course of 1 day correspond to a daily deposition of $8 \times 10^{16}$ molecules $\mathrm{m}^{-2}$ of $\mathrm{H}_{2} \mathrm{O}_{2}$ and a daily emission of $7 \times 10^{16}$ molecules $\mathrm{m}^{-2}$ of $\mathrm{HCHO}$.

During the measuring period we had the opportunity to measure fluxes during one night with a new snow event. Fluxes calculated for the period between 29 June and 1 July are shown in Fig. 5. While fluxes measured on 29 June and the first half of 30 June reflect typical diel variations for both compounds close to average diel variations depicted in Fig. 4, the results for the night from 30 June to 1 July demonstrate the impact of $<1 \mathrm{~cm}$ new snow that precipitated in the course of this night. $\mathrm{H}_{2} \mathrm{O}_{2}$ and $\mathrm{HCHO}$ fluxes clearly show strong emissions during the night at a time when normally slight emission or deposition occur. Highest emission rates for $\mathrm{H}_{2} \mathrm{O}_{2}$ were observed between 21:00 on 30 June and 2:00 on 1 July, whereas highest emission rates for $\mathrm{HCHO}$ were measured $\sim 2-3 \mathrm{~h}$ later. Total amounts released were $6.7 \times 10^{17}$ molecules $\mathrm{m}^{-2}$ of $\mathrm{H}_{2} \mathrm{O}_{2}$ between 21:00 and 2:00 and $8.1 \times 10^{16}$ molecules $\mathrm{m}^{-2}$ of $\mathrm{HCHO}$ between 24:00 and 4:00.

\section{Discussion}

The most prominent feature in the $\mathrm{H}_{2} \mathrm{O}_{2}$ gas-phase concentrations is its distinct diel variation that has been 


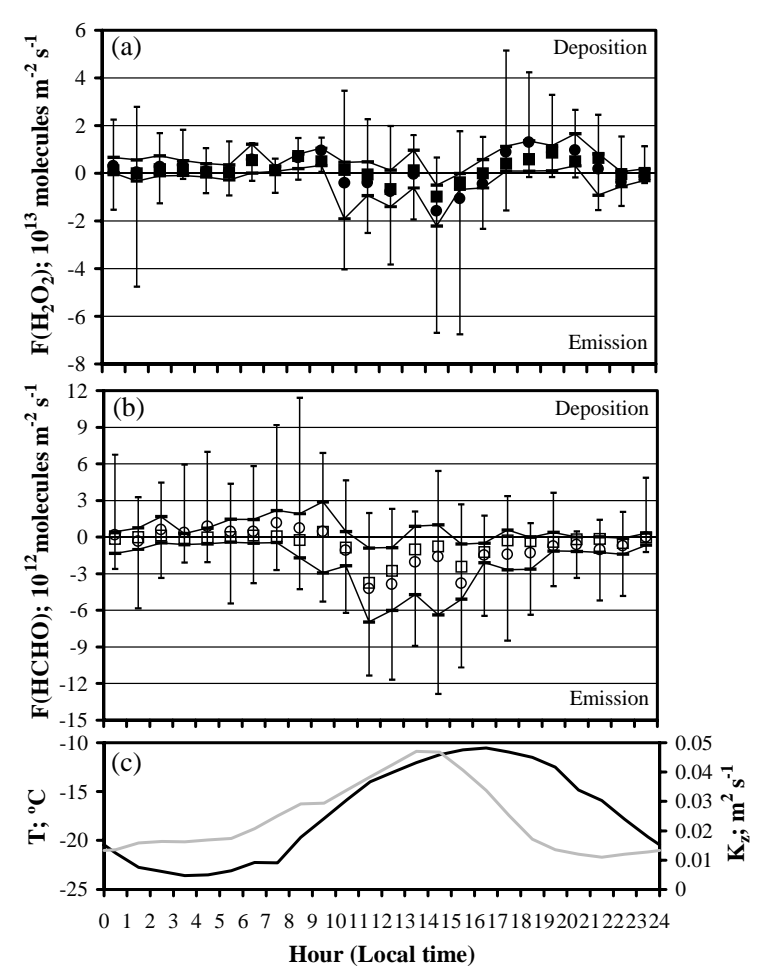

Fig. 4. Diel variations measured at Summit, Greenland, between 16 June and 7 July 2000. $\mathrm{H}_{2} \mathrm{O}_{2}$ (a) and $\mathrm{HCHO}$ (b) fluxes. The average and median of the data in each $1 \mathrm{~h}$ bin are indicated by a circle and a box, respectively; the vertical lines connected by solid lines indicate the middle $50 \%$ of the data; and the error bars the middle $95 \%$ of the data, (c) $1 \mathrm{~h}$ averages of surface snow temperature and eddy diffusion coefficient.

observed in all previous studies at Summit (Sigg et al., 1992; Bales et al., 1995a,b; Fuhrer et al., 1996; McConnell et al., 1997b; Hutterli et al., 2001). For example, during this field season highest concentrations were found between 17:00 and 21:00 with an average of $0.82 \mathrm{ppbv}$, whereas lowest values averaging to $0.42 \mathrm{ppb}$ were measured between 0:00 and 3:00. In comparison to previous studies, the $\mathrm{H}_{2} \mathrm{O}_{2}$ concentrations are lower and the diel cycle is less pronounced. In addition, we observed a diel cycle in the $\mathrm{HCHO}$ concentrations in the gas phase with highest concentrations between 7:00 and 10:00 and lowest concentrations between midnight and 3:00. The averages for these $3 \mathrm{~h}$ periods are 150 and 95 pptv. This diel variation is less marked compared to $\mathrm{H}_{2} \mathrm{O}_{2}$ and has not been observed in former studies at Summit (Fuhrer et al., 1996; Hutterli et al., 1999). The average $\mathrm{HCHO}$ concentrations in 2000 were also lower compared to observations at Summit in 1996 (Hutterli et al., 1999). The differences between this study and former results are possibly due to the meteorological conditions. During long periods, the wind speed was very low $\left(<4 \mathrm{~m} \mathrm{~s}^{-1}\right)$. Moreover, fresh snowfalls, which
Table 1

Gas-phase inventories, averaged exchange rates, and net photochemical production or destruction rates measured during the field season 2000 at Summit, Greenland

\begin{tabular}{|c|c|c|}
\hline & $\mathrm{H}_{2} \mathrm{O}_{2}$ & $\mathrm{HCHO}$ \\
\hline $\begin{array}{l}\text { Maximum gas phase } \\
\text { inventory }{ }^{\mathrm{a}} \text {, molecules } \mathrm{m}^{-2}\end{array}$ & $1.4 \times 10^{18}$ & $2.5 \times 10^{17}$ \\
\hline $\begin{array}{l}\text { Minimum gas phase } \\
\text { inventory }{ }^{\mathrm{b}} \text {, molecules } \mathrm{m}^{-2}\end{array}$ & $0.4 \times 10^{18}$ & $0.9 \times 10^{17}$ \\
\hline $\begin{array}{l}\text { Difference in gas phase } \\
\text { inventory; molecules } \mathrm{m}^{-2}\end{array}$ & $1.0 \times 10^{18}$ & $1.6 \times 10^{17}$ \\
\hline $\begin{array}{l}\text { Daily deposition } \\
\text { molecules } \mathrm{m}^{-2}\end{array}$ & $\left(2.7_{-2.3}^{+2.9}\right) \times 10^{17}$ & $\begin{array}{l}\left(1.8_{-1.8}^{+4.5}\right) \times \\
10^{16}\end{array}$ \\
\hline $\begin{array}{l}\text { Daily emission } \\
\text { molecules }^{-2} \\
\left(8.8_{-7.7}^{+10.8}\right) \times 10^{16}\end{array}$ & $\left(1.9_{-1.7}^{+2.1}\right) \times 10^{17}$ & \\
\hline $\begin{array}{l}\text { Daily net exchange } \\
\text { molecules } \mathrm{m}^{-2} \\
\left(7.0_{-12.2}^{+12.6}\right) \times 10^{16}\end{array}$ & $\left(0.8_{-4.3}^{+4.6}\right) \times 10^{17}$ & \\
\hline $\begin{array}{l}\text { Daily net photochemical } \\
\text { production/destruction }^{\text {d. }}\end{array}$ & $\begin{array}{l}\text { Deposition } \\
1.5 \times 10^{18}\end{array}$ & $\begin{array}{l}\text { Emission } \\
6.5 \times 10^{17}\end{array}$ \\
\hline
\end{tabular}
molecules $\mathrm{m}^{-2}$

\section{Destruction}

Total emission after new snow event;

molecules $\mathrm{m}^{-2}$
Production

$$
6.7 \times 10^{17}
$$$$
8.1 \times 10^{16}
$$

\footnotetext{
${ }^{\text {a }}$ Estimated using an ABL height of $90 \mathrm{~m}$ (Helmig et al., 2002), $\left[\mathrm{H}_{2} \mathrm{O}_{2}\right]=0.82 \mathrm{ppbv}$, and $[\mathrm{HCHO}]=150$ pptv.

${ }^{\mathrm{b}}$ Estimated using an ABL height of $50 \mathrm{~m}$ (see text), $\left[\mathrm{H}_{2} \mathrm{O}_{2}\right]=0.42 \mathrm{ppbv}$, and $[\mathrm{HCHO}]=95 \mathrm{pptv}$.

${ }^{\mathrm{c}}$ Errors are calculated using the maxima and minima of the middle $50 \%$ of the data of the fluxes indicated in Fig. 4.

${ }^{\mathrm{d}}$ Estimated using an ABL height of $90 \mathrm{~m}$ and average rates given by Yang et al. (2002) for 5:00-21:00.
}

can substantially disturb diel variations of $\mathrm{H}_{2} \mathrm{O}_{2}$ and HCHO (see below), occurred only twice during the measuring period.

The observed fluxes show that $\mathrm{H}_{2} \mathrm{O}_{2}$ and $\mathrm{HCHO}$ are exchanged between the surface snow and the gas phase. Since fluxes in both directions occur, the surface snowpack can be considered as a temporary reservoir for $\mathrm{H}_{2} \mathrm{O}_{2}$ and $\mathrm{HCHO}$ during the night. While this mechanism was suggested for $\mathrm{H}_{2} \mathrm{O}_{2}$ by Sigg et al. (1992), we demonstrate here that it can also be applied to HCHO. Obviously, such a mechanism has the potential to contribute to observed diel variations. Likewise, a comparison of the observed concentrations with the direction of the fluxes demonstrates partial agreement. The emissions of both compounds during the day and deposition during the night can explain elevated concentrations at daytime. These results are in agreement with previous measurements of $\mathrm{H}_{2} \mathrm{O}_{2}$ fluxes above 

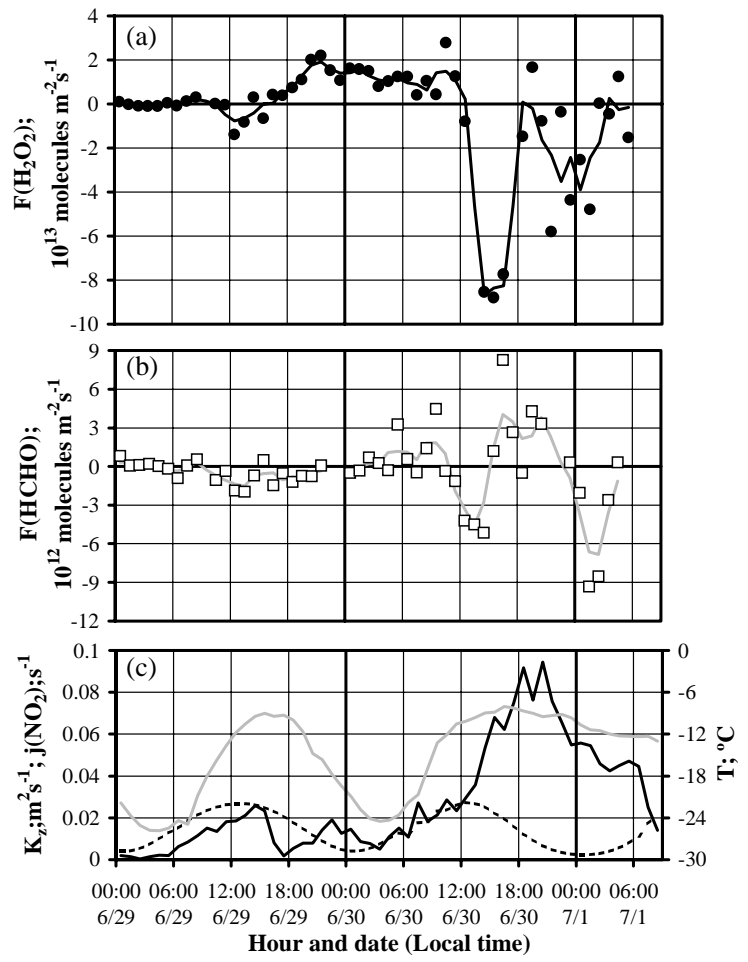

Fig. 5. $\mathrm{H}_{2} \mathrm{O}_{2}$ and $\mathrm{HCHO}$ fluxes, surface snow temperature, eddy diffusion coefficient, and photolysis rate of $\mathrm{NO}_{2}$ measured at Summit, Greenland, between 29 June and 1 July 2000, (a) $\mathrm{H}_{2} \mathrm{O}_{2}$ flux. Filled circles mark $1 \mathrm{~h}$ averages; line represents $3 \mathrm{~h}$ running averages, (b) HCHO flux. Open squares mark $1 \mathrm{~h}$ averages; line represents $3 \mathrm{~h}$ running averages, (c) $1 \mathrm{~h}$ averages of surface snow temperature (gray line), eddy diffusion coefficient (black line), and $j\left(\mathrm{NO}_{2}\right)$ (dashed line).

the snow surface (Hutterli et al., 2001) indicating that emissions with highest values between 8:00 and 16:00 contributed to observed diel variations in $\mathrm{H}_{2} \mathrm{O}_{2}$ gasphase concentrations.

To evaluate the impact of the exchange on the diel variations in the gas phase, we compare the change in the total amount present in the ABL (=inventory) with the measured daily emission and deposition. Table 1 shows estimated maximum and minimum inventories in the gas phase using maximum and minimum concentrations of 0.82 and $0.42 \mathrm{ppbv}$ for $\mathrm{H}_{2} \mathrm{O}_{2}$ and 150 and 95 pptv for $\mathrm{HCHO}$. We also used averaged ABL heights of $90 \mathrm{~m}$ during daytime (Helmig et al., this issue) and $50 \mathrm{~m}$ during nighttime corresponding to the median of mixing heights calculated from friction velocities and Obukhov lengths for stable conditions between 0:00 and 3:00 (Seibert et al., 2000). Then, the difference in the maximum and minimum inventories can be compared with daily deposited and emitted amounts, which are summarized in Table 1. In general, the results suggest that bi-directional fluxes in the boundary layer are an important mechanism influencing diel cycles of $\mathrm{H}_{2} \mathrm{O}_{2}$ and $\mathrm{HCHO}$ in the ABL over the snowpack at Summit. However, the diel variations cannot be explained solely by the exchange with the snow pack. Moreover, increase and decrease of the concentrations do not coincide with changes in the direction of the fluxes. For example, $\mathrm{HCHO}$ concentrations start rising at 4:00 and falling at 21:00, although deposition and emission still continue until 9:00 and 1:00, respectively. A similar time shift is apparent in the case of $\mathrm{H}_{2} \mathrm{O}_{2}$.

Photochemical reactions governing the production and destruction of $\mathrm{H}_{2} \mathrm{O}_{2}$ and $\mathrm{HCHO}$ involve $\mathrm{OH}$ and $\mathrm{HO}_{2}$ reactions and direct photolysis. Since $\mathrm{OH}$ and $\mathrm{HO}_{2}$ concentrations closely follow diel variations in $\mathrm{UV}$ radiation, photochemical processing of $\mathrm{H}_{2} \mathrm{O}_{2}$ and $\mathrm{HCHO}$ becomes more vigorous with increasing radiation intensity. In fact, increase and decrease of the $\mathrm{H}_{2} \mathrm{O}_{2}$ and $\mathrm{HCHO}$ diel variations at the transitions between day and night seem to be dominated by photochemical reactions since both correlate well with $j\left(\mathrm{NO}_{2}\right)$ (Fig. 5) which corresponds to the intensity of UV radiation. Yang et al. (this issue) report average production and destruction rates for several species obtained from photolysis rates and calculated $\mathrm{OH}$ and $\mathrm{HO}_{2}$ concentrations. Their results show that the photochemical sources and sinks of $\mathrm{H}_{2} \mathrm{O}_{2}$ and $\mathrm{HCHO}$ are not in equilibrium resulting in a net production of $\mathrm{H}_{2} \mathrm{O}_{2}$ and a net destruction of HCHO (Table 1). Although the exchange with the surface snow partly counteracts the photochemical imbalances, it accounts only for $<10 \%$ of photochemically produced $\mathrm{H}_{2} \mathrm{O}_{2}$ and destroyed $\mathrm{HCHO}$. Note, that the photochemical production of $\mathrm{HCHO}$ is uncertain since it depends on the branching ratio for the reaction of methyl peroxyradicals with either $\mathrm{NO}$ or $\mathrm{HO}_{2}$. The net destruction given in Table 1 is calculated using a ratio of 0.13 (Yang et al., this issue) and would turn into a net photochemical production at a ratio of higher than 0.66 . The non-equilibrium of photochemical transformation plus exchange at the snow surface for $\mathrm{H}_{2} \mathrm{O}_{2}$ and $\mathrm{HCHO}$ indicates that additional processes must be considered to fully explain the diel variations and are discussed in the following.

One important removal mechanism for $\mathrm{H}_{2} \mathrm{O}_{2}$ is the formation of fog (Bergin et al., 1996; Hutterli et al., 2001) that regularly occurred at night during the field season. Bergin et al. (1996) demonstrated that $\mathrm{H}_{2} \mathrm{O}_{2}$ could be fully depleted in the presence of fog if equilibrium according to Henry's law between concentrations in the fog droplets and in the gas phase is assumed. A calculated $\mathrm{H}_{2} \mathrm{O}_{2}$ flux of $5.5 \times 10^{18}$ molecules $\mathrm{m}^{-2}$ was obtained in a case study of a fog event at Summit lasting for $10 \mathrm{~h}$ during one night (Bergin et al., 1996). This value is more than 10 times the daily dry deposition obtained in this study (Table 1) demonstrating that fog deposition can be very effective and is sufficient to remove the photochemically 
produced excess $\mathrm{H}_{2} \mathrm{O}_{2}$. The transfer of $\mathrm{HCHO}$ into droplets and subsequent deposition to the surface snow could also cause an additional deposition of HCHO. Due to the lower Henry's law coefficient the removal is probably less effective in agreement with the less pronounced diel cycle.

Another possible mechanism having the potential to influence gas-phase concentration in the $\mathrm{ABL}$ is the entrainment of air from above into the ABL due to increasing mixing layer heights during the course of the day. This can either lead to an increase or decrease of $\mathrm{H}_{2} \mathrm{O}_{2}$ and $\mathrm{HCHO}$ depending on concentrations in the free troposphere relative to concentrations in the ABL. This process might be reflected by the fast increase of $\mathrm{HCHO}$ and $\mathrm{H}_{2} \mathrm{O}_{2}$ during the morning when the shallow and stable nocturnal ABL is obliterated assuming that the deposition during the night decreases the concentrations in the ABL compared to the layer above. Overall, further studies to distinguish between $\mathrm{H}_{2} \mathrm{O}_{2}$ and $\mathrm{HCHO}$ in the gas phase and in fog are needed to fully understand the cycling between the ABL and the surface snow. In addition, detailed investigations of the structure of the ABL are necessary to elaborate the impact of emission, deposition, and vertical transport on $\mathrm{H}_{2} \mathrm{O}_{2}$ and $\mathrm{HCHO}$ concentrations in the ABL.

The new snow event and its effect observed during the night from 30 June to 1 July demonstrates that the system ABL plus underlying snowpack cannot be regarded as a closed system with negligible exchange at the upper and lower boundary. New snow influences the surface snow concentrations as well as the magnitude and direction of the flux between snow and ABL as observed during this specific night (Fig. 4). The total amount of $\mathrm{H}_{2} \mathrm{O}_{2}$ released during the night was more than 3 times the amount normally released during 1 day (Table 1). This difference was less dramatic in the case of $\mathrm{HCHO}$, and the amount emitted during the night with the new snow event almost equalled the amount normally released during the course of 1 day. Accordingly, the effect on the concentrations in the $\mathrm{ABL}$ is more pronounced in the case of $\mathrm{H}_{2} \mathrm{O}_{2}$ (Fig. 1). In most of the nights before and after the event, $\mathrm{H}_{2} \mathrm{O}_{2}$ concentrations dropped to values around $0.2-0.4 \mathrm{ppbv}$ during the night while in this specific night considerably higher concentrations between 0.6 and $1.1 \mathrm{ppbv}$ were observed. HCHO concentrations showed almost no deviation from the normal diel variation. However, another effect of the synoptic weather situation concealed the possible impact of extraordinary emissions. Unstable conditions reflected in the high values of the eddy diffusion coefficients (Fig. 5) prevented the development of a shallow nocturnal ABL, thus diluting the emitted amounts in a much deeper layer compared to other nights. While no measurements of the $\mathrm{H}_{2} \mathrm{O}_{2}$ and $\mathrm{HCHO}$ concentrations in the new snow of this event are available, previous measurements have revealed that in general new snow initially contains higher concentrations of both compounds compared to surface snow (Bales et al., 1995b) and that the concentrations drop rapidly within a few hours (Hutterli et al., 1999, 2001).

The emitted amount and the timing of the emission are analyzed to estimate the lability of both compounds in the new snow. This estimate can only constitute an upper limit since the higher snow temperature during the specific night (Fig. 5) could also cause enhanced emissions of deeper snow layers. Surface snow samples were taken on 1 July at 8:00 after the new snow event. We found $\mathrm{H}_{2} \mathrm{O}_{2}$ and $\mathrm{HCHO}$ concentrations of 12.1 and $0.65 \mu \mathrm{M}$ in the top $1 \mathrm{~cm}$ of the snow and densities of 0.05 and $0.06 \mathrm{~g} \mathrm{~cm}^{-3}$, respectively, corresponding to $\mathrm{H}_{2} \mathrm{O}_{2}$ and $\mathrm{HCHO}$ amounts of $3.6 \times 10^{18}$ molecules $^{-2}$ and $2.3 \times 10^{17}$ molecules $\mathrm{m}^{-2}$ after the emission during the past night. Adding the emitted amounts during the night (Table 1) leads to an estimate of the total amount in the new snow before precipitation resulting in $4.3 \times 10^{18}$ molecules $\mathrm{m}^{-2}$ of $\mathrm{H}_{2} \mathrm{O}_{2}$ and $3.1 \times 10^{17}$ molecules $\mathrm{m}^{-2}$ of HCHO. The comparison shows more than $25 \%$ of the $\mathrm{HCHO}$ amount, but $<16 \%$ of the $\mathrm{H}_{2} \mathrm{O}_{2}$ amount was available for emission during the first night after precipitation indicating that a higher percentage of $\mathrm{HCHO}$ is present at the surface compared to $\mathrm{H}_{2} \mathrm{O}_{2}$.

Couch et al. (2000) demonstrated that the immediate release after snowfall can be attributed to the surfacebound component. Accordingly, a laboratory investigation of the uptake of $\mathrm{H}_{2} \mathrm{O}_{2}$ demonstrated that it is accumulated on the ice surface as well as incorporated into the bulk ice with an estimated upper limit of $20 \%$ present at the surface at $-12.5^{\circ} \mathrm{C}$ (Conklin et al., 1993). This limit is slightly higher than the released amount obtained in our study, which also represents only an upper limit for the amount present at the surface layer since during the first hours after precipitation recrystallization occurs that also leads to the evaporation of part of the bulk ice crystals.

\section{Conclusions}

Long-term measurements revealed that HCHO concentrations in the ABL over the snowpack at Summit, Greenland follow a diel cycle similar to $\mathrm{H}_{2} \mathrm{O}_{2}$ diel variations with higher concentrations during the day and lower concentrations during the night. These diel variations are at least partly caused by bi-directional fluxes of both species between the atmosphere and the underlying snowpack indicating that the snow acts as a temporary reservoir during the course of a day. During this study the emitted and deposited amounts of $\mathrm{H}_{2} \mathrm{O}_{2}$ and HCHO nearly canceled each other during $24 \mathrm{~h}$ resulting in small net deposition of $\mathrm{H}_{2} \mathrm{O}_{2}$ and net emission of $\mathrm{HCHO}$. Photochemistry as well as emission and deposition of $\mathrm{H}_{2} \mathrm{O}_{2}$ and $\mathrm{HCHO}$ must be taken into 
account to reproduce diel variations in the ABL. Due to the importance of both compounds in tropospheric photochemistry the bi-directional exchange should be included in modeling studies undertaken to investigate photochemical processes above snow covered areas like $\mathrm{O}_{3}$ depletion or halogen activation occurring in the polar ABL. Since no measurements of the ABL height and no measurements above the ABL were performed the role of changing mixing heights and entrainment from higher layers cannot be addressed. These measurements are necessary in future studies to establish a comprehensive budget of $\mathrm{H}_{2} \mathrm{O}_{2}$ and $\mathrm{HCHO}$ in the $\mathrm{ABL}$ in polar regions and to reproduce observed diel cycles.

New snow disturbs regular uptake and release processes leading to the emission of considerable quantities of $\mathrm{H}_{2} \mathrm{O}_{2}$ and $\mathrm{HCHO}$ into the $\mathrm{ABL}$ within hours after the beginning of the precipitation event. A rough analysis of the new snow event shows that more than $25 \%$ of the $\mathrm{HCHO}$ and almost $16 \%$ of the $\mathrm{H}_{2} \mathrm{O}_{2}$ incorporated in the new snow are available for rapid release after precipitation. Although a larger $\mathrm{HCHO}$ fraction was released, the emission maximum was delayed by several hours compared to $\mathrm{H}_{2} \mathrm{O}_{2}$.

\section{Acknowledgements}

Financial support by the National Science Foundation (NSF), grants OPP-9813442 and OPP-9813311, is gratefully acknowledged. HWJ thanks the Deutsche Forschungsgemeinschaft (DFG) for a research stipend. Moreover, NSF funded the participation of CK through the program Teachers Experiencing Antarctica and the Arctic (TEA). Assistance and equipment during the field experiments were provided by the Summit summer crew, VECO Polar Resources, the Air National Guard, and the University of Bern, Switzerland.

\section{References}

Ariya, P.A., Jobson, B.T., Sander, R., Niki, H., Harris, G.W., Hopper, J.F., Anlauf, K.G., 1998. Measurements of $\mathrm{C}_{2}-\mathrm{C}_{7}$ hydrocarbons during the polar sunrise experiment 1994: further evidence for halogen chemistry in the troposphere. Journal of Geophysical Research 103, 13169-13180.

Bales, R.C., McConnell, J.R., Losleben, M.V., Conklin, M.H., Fuhrer, K., Neftel, A., Dibb, J.E., Kahl, J.D.W., Stearns, C.R., 1995a. Diel variations of $\mathrm{H}_{2} \mathrm{O}_{2}$ in Greenland: a discussion of the cause and effect relationship. Journal of Geophysical Research 100, 18661-18668.

Bales, R.C., Losleben, M.V., McConnell, J.R., Fuhrer, K., Neftel, A., 1995b. $\mathrm{H}_{2} \mathrm{O}_{2}$ in snow, air and open pore space in firn at Summit, Greenland. Geophysical Research Letters 22, 1261-1264.

Barrie, L.A., Bottenheim, J.W., Schnell, R.C., Crutzen, P.J., Rasmussen, R.A., 1988. Ozone destruction and photoche- mical reactions at polar sunrise in the lower Arctic atmosphere. Nature 334, 138-141.

Barrie, L.A., Staebler, R., Toom, D., Georgi, B., den Hartog, G., Landsberger, S., Wu, D., 1994. Arctic aerosol sizesegregated chemical observations in relation to ozone depletion during Polar Sunrise Experiment 1992. Journal of Geophysical Research 99, 25439-25451.

Bergin, M.H., Pandis, S.N., Davidson, C.I., Jaffrezo, J.-L., Dibb, J.E., Russell, A.G., Kuhns, H.D., 1996. Modeling of the processing and removal of trace gas and aerosol species by Arctic radiation fogs and comparison with measurements. Journal of Geophysical Research 101, 14465-14478.

Bottenheim, J.W., Barrie, L.A., Atlas, E., Heidt, L.E., Niki, H., Rasmussen, R.A., Shepson, P.B., 1990. Depletion of lower tropospheric ozone during Arctic spring: the Polar Sunrise Experiment 1988. Journal of Geophysical Research 95, 18555-18568.

Businger, J.A., Wyngaard, J.C., Izumi, Y., Bradley, E.F., 1971. Flux-profile relationships in the atmospheric surface layer. Journal of Atmospheric Sciences 78, 181-189.

Chance, K., Palmer, P.I., Spurr, R.J.D., Martin, R.V., Kurosu, T.P., Jacob, D.J., 2000. Satellite observations of formaldehyde over North America from GOME. Geophysical Research Letters 27, 3461-3464.

Conklin, M.H., Sigg, A., Neftel, A., Bales, R.C., 1993. Atmosphere-snow transfer for $\mathrm{H}_{2} \mathrm{O}_{2}$ : microphysical considerations. Journal of Geophysical Research 98, 1836718376.

Couch, T.L., Sumner, A.L., Dassau, T.M., Shepson, P.B., Honrath, R.E., 2000. An investigation of the interaction of carbonyl compounds with the snowpack. Geophysical Research Letters 27, 2241-2244.

Crawford, J., Davis, D., Olsen, J., Chen, G., Liu, S., Gregory, G., Barrick, J., Sachse, G., Sandholm, S., Heikes, B., Singh, H., Blake, D., 1999. Assessment of upper tropospheric $\mathrm{HO}_{x}$ sources over the tropical pacific based on NAS GTE/PEM data: net effect on $\mathrm{HO}_{x}$ and other photochemical parameters. Journal of Geophysical Research 104, 16255-16273.

Cullen, N., Steffen, K., 2001. Unstable near-surface boundary conditions in summer on top of the Greenland ice sheet. Geophysical Research Letters 28, 4491-4493.

De Serves, C., 1994. Gas phase formaldehyde and peroxide measurements in the Arctic atmosphere. Journal of Geophysical Research 99, 25391-25398.

Dyer, A.J., 1974. A review of flux-profile relationships. Boundary-Layer Meteorology 7, 363-372.

Fuhrer, K., Hutterli, M., McConnell, J.R., 1996. Overview of recent field experiments for the study of the air-snow transfer of $\mathrm{H}_{2} \mathrm{O}_{2}$ and HCHO. In: Wolff, E., Bales, R.C. (Eds.), Chemical Exchange between the Atmosphere and Polar Snow. NATO ASI Series I, Vol. 43. Springer, Berlin, pp. 307-318.

Helmig, D., Boulter, J., David, D., Birks, J., Cullen, N., Steffen, K., 2002. Ozone and meteorological boundary-layer conditions at Summit, Greenland. Atmospheric Environment 36, 2595-2608.

Honrath, R.E., Lu, Y., Peterson, M.C., Dibb, J.E., Arsenault, M.A., Cullen, N.J., Steffen, K., 2002. Vertical fluxes of $\mathrm{NO}_{x}, \mathrm{HONO}$ and $\mathrm{HNO}_{3}$ above the snowpack at summit, greenland. Atmospheric Environment 36, 2629-2640. 
Hutterli, M.A., Röthlisberger, R., Bales, R.C., 1999. Atmosphere-to-snow-to-firn transfer studies of HCHO at Summit, Greenland. Geophysical Research Letters 26, 16911694.

Hutterli, M.A., McConnell, J.R., Stewart, R.W., Jacobi, H.-W., Bales, R.C., 2001. Impact of temperature-driven cycling of hydrogen peroxide $\left(\mathrm{H}_{2} \mathrm{O}_{2}\right)$ between air and snow on the planetary boundary layer. Journal of Geophysical Research 106, 15395-15404.

Jaeglé, L., Jacob, D.J., Brune, W.H., Faloona, I., Tan, D., Heikes, B.G., Kondo, Y., Sachse, G.W., Anderson, B., Gregory, G.L., Singh, H.B., Pueschel, R., Ferry, G., Blake, D.R., Shetter, R.E., 2000. Photochemistry of $\mathrm{HO}_{x}$ in the upper troposphere at northern midlatitudes. Journal of Geophysical Research 105, 3877-3892.

Jenkin, M.E., Clemitshaw, K.C., 2000. Ozone and other secondary photochemical pollutants: chemical processes governing their formation in the planetary boundary layer. Atmospheric Environment 34, 2499-2527.

Jobson, B.T., Niki, H., Yokouchi, Y., Bottenheim, J., Hopper, F., Leaitch, R., 1994. Measurements of $\mathrm{C}_{2}-\mathrm{C}_{6}$ hydrocarbons during the Polar Sunrise 1992 Experiment: evidence for $\mathrm{Cl}$ atom and $\mathrm{Br}$ atom chemistry. Journal of Geophysical Research 99, 25355-25368.

Kaimal, J.C., Finnigan, J.J., 1994. Atmospheric Boundary Layer Flows: their Structure and Measurement. Oxford University Press, Cambridge.

Lee, M., Heikes, B.G., O'Sullivan, D.W., 2000. Hydrogen peroxide and organic hydroperoxide in the troposphere: a review. Atmospheric Environment 34, 3475-3494.

McConnell, J.C., Henderson, G.S., Barrie, L., Bottenheim, J., Niki, H., Langford, C.H., Templeton, E.M.J., 1992. Photochemical bromine production implicated in arctic boundary-layer ozone depletion. Nature 355, 150-152.

McConnell, J.R., Winterle, J.R., Bales, R.C., Thompson, A.M., Stewart, R.W., 1997a. Physically based inversion of surface snow concentrations of $\mathrm{H}_{2} \mathrm{O}_{2}$ to atmospheric concentrations at South Pole. Geophysical Research Letters 24, 441-444.

McConnell, J.R., Bales, R.C., Winterle, J.R., Kuhns, H., Stearns, C.R., 1997b. A lumped parameter model for the atmosphere-to-snow transfer function for hydrogen peroxide. Journal of Geophysical Research 102, 26809-26818.

Michalowski, B.A., Francisco, J.S., Li, S.-M., Barrie, L.A., Bottenheim, J.W., Shepson, P.B., 2000. A computer model study of multiphase chemistry in the Arctic boundary layer during polar sunrise. Journal of Geophysical Research 105, 15131-15145.

Mickle, R.E., Bottenheim, J.W., Leaitch, W.R., Evans, W., 1989. Boundary layer ozone depletion during AGASP-II. Atmospheric Environment 23, 2443-2449.

Neftel, A., Bales, R.C., Jacob, D.J., 1995. $\mathrm{H}_{2} \mathrm{O}_{2}$ and $\mathrm{HCHO}$ in polar snow and their relation to atmospheric chemistry. In: Delmas, R. (Ed.), Ice Core Studies of Global Biogeochemical Cycles, NATO ASI Series I, Vol. 30. Springer, Berlin, pp. 249-264.

Ramacher, B., Rudolph, J., Koppmann, R., 1999. Hydrocarbon measurements during tropospheric ozone depletion events: evidence for halogen atom chemistry. Journal of Geophysical Research 104, 3633-3653.

Riedel, K., Weller, R., Schrems, O., 1999. Variability of formaldehyde in the Antarctic troposphere. Physical Chemistry Chemical Physics 1, 5523-5527.

Rudolph, J., Fu, B.R., Thompson, A., Anlauf, K., Bottenheim, J., 1999. Halogen atom concentrations in the arctic troposphere derived from hydrocarbon measurements: impact on the budget of formaldehyde. Geophysical Research Letters 26, 2941-2944.

Sander, R., Vogt, R., Harris, G.W., Crutzen, P.J., 1997. Modeling the chemistry of ozone, halogen compounds, and hydrocarbons in the Arctic troposphere during spring. Tellus 49B, 522-532.

Seibert, P., Beyrich, F., Gryning, S.-E., Joffre, S., Rasmussen, A., Tercier, P., 2000. Review and intercomparison of operational methods for the determination of the mixing height. Atmospheric Environment 34, 1001-1027.

Shepson, P.B., Shirju, A.-P., Hopper, J.F., Barrie, L.A., Young, V., Niki, H., Dryfhout, H.J., 1996. Sources and sinks of carbonyl compounds in the Arctic Ocean boundary layer: Polar Ice Flow Experiment. Journal of Geophysical Research 101, 21081-21089.

Sigg, A., Staffelbach, T., Neftel, A., 1992. Gas phase measurements of hydrogen peroxide in Greenland and their meaning for the interpretation of $\mathrm{H}_{2} \mathrm{O}_{2}$ records in ice cores. Journal of Atmospheric Chemistry 14, 223-232.

Solberg, S., Schmidbauer, N., Semb, A., Strodal, F., Hov, Ø., 1996. Boundary layer ozone depletion as seen in the Norwegian Arctic in spring. Journal of Atmospheric Chemistry 23, 301-332.

Solberg, S., Dye, C., Walker, S.-E., Simpson, D., 2001. Longterm measurements and model calculations of formaldehyde at rural European monitoring sites. Atmospheric Environment 35, 195-207.

Staffelbach, T., Neftel, A., Stauffer, B., Jacob, D., 1991. A record of atmospheric methane sink from formaldehyde in polar ice cores. Nature 349, 603-605.

Sumner, A.L., Shepson, P.B., 1999. Snowpack production of formaldehyde and its effect on the Arctic troposphere. Nature 398, 230-233.

Thompson, A.M., Chappellaz, J.A., Fung, I.Y., Kucsera, T.L., 1993. The atmospheric $\mathrm{CH}_{4}$ increase since the last glacial maximum, 2, interactions with oxidants. Tellus B 45, 242357.

Weller, R., Schrems, O., Boddenberg, A., Gäb, S., Gautrois, M., 2000. Meridional distribution of hydroperoxides and formaldehyde in the marine boundary layer of the Atlantic $\left(48^{\circ} \mathrm{N}-35^{\circ} \mathrm{S}\right)$ measured during the Albatross campaign. Journal of Geophysical Research 105, 14401-14412.

Yang, J., Honrath, R.E., Peterson, M.C., Dibb, J.E., Sumner, A.L., Shepson, P.B., Frey, M., Jacobi, H.-W., Swanson, A., Blake, N., 2002. Impacts of snowpack photochemistry on levels of $\mathrm{OH}$ and peroxy radicals at Summit, Greenland. Atmospheric Environment 36, 2523-2534. 